\title{
Evaluation of clinicopathological parameters and its relation with immunohistochemical expressions in breast carcinoma: A hospital based cross- sectional observational study
}

\author{
Mala Mukherjee ${ }^{1}$, Karabi Konar,", Arghya Bandopadhyay $^{3}$, Shatavisa Mukherjee ${ }^{4}$, Nikhil Era $^{5}$ \\ ${ }^{1,3,5}$ Assistant Professor, ${ }^{2}$ Associate Professor, ${ }^{4}$ Research Scholar, ${ }^{1-3}$ Dept. of Pathology, ${ }^{4,5}$ Dept. of Pharmacology, ${ }^{1,5}$ Mata Gujari \\ Memorial Medical College, Bihar, ${ }^{\mathbf{2} 3}$ Burdwan Medical College, Burdwan, West Bengal, ${ }^{4}$ Calcutta School of Tropical Medicine, \\ Kolkata, West Bengal, India
}

*Corresponding Author:

Email: newlymala@yahoo.com

\begin{abstract}
Introduction: Knowhow of HER-2/neu proto-oncogene amplification and/or over expression and presence of hormone (estrogen and progesterone) receptors in tumour tissue is one of the most crucial checkpoints in the therapy of breast cancer. The present study aimed to evaluate various clinicopathological parameters in the mastectomy specimens and to probe for any relation with its immunohistochemical expressions.

Materials and Methods: Detailed clinical examination of the breast and the lump was done and presence of any axillary or cervical lymph nodes was also noted. After clinical examination, tumour size from the mastectomy specimen was recorded; number of lymph nodes was noted. The modified radical mastectomy samples after surgical removal, were fixed in formalin and sent for histopathological examination where tissue processing and staining with haematoxylin \& eosin was done. Post mastectomy grading of the malignant breast lesion was done. Immunostaining of the HER-2 protein, Estrogen receptors (ER) \& Progesterone receptors (PR) was performed for all specimens.

Results: The present study showed a significant inverse association between ER and PR expression and higher tumour grades, axillary lymph node metastases and stage. HER-2/neu overexpression is significantly associated with clinicopathlogical parameters like younger age group, increased tumour size, higher tumour grades, and higher clinical staging. Significant association was seen between tumour size and lymph node metastases implying that lymph node metastasis increases with larger tumour size.
\end{abstract}

Keywords: Breast Carcinoma, HER2/Neu receptor, Estrogen Receptor, Progesterone Receptor.

\section{Introduction}

Breast carcinoma is the most common malignant tumour and the leading cause of cancer death in women, with more than one million cases occurring worldwide annually. ${ }^{1}$ Breast cancer is the most common cancer in women worldwide, with nearly 1.7 million new cases diagnosed in 2012 (second most common cancer overall). This represents about $12 \%$ of all new cancer cases and $25 \%$ of all cancers in women. It is the fifth most common cause of death from cancer in women. ${ }^{2}$ The most common type of carcinoma in breast is infiltrative ductal carcinoma (70\%), lobular carcinoma is the 2nd most common histological group followed by smaller groups such as medullary carcinoma, mucinous carcinoma, comedo carcinoma, Paget's disease, papillary carcinoma, tubular carcinoma and inflammatory carcinoma. ${ }^{3}$

Although clinical signs of disseminated disease occur in fewer than $10 \%$ of women at the time of diagnosis, the disease relapses in the form of metastasis within 5 years of surgery in about half of apparently localized tumors. Many studies have been concerned about its pathogenesis, biological behavior, and it has been documented that breast cancer is a heterogeneous disease with variable biological and clinical characteristics because of its different genetic makeup, ${ }^{4}$ so it is difficult to predict the occurrence of distant metastases since breast cancer is a heterogeneous disease encompassing complex pathologic entities Thus, there is a need for new and effective breast cancer therapies with existing ones.

HER-2/neu proto-oncogene amplification and/or over expression is one of the most important alterations encountered in breast cancer. HER-2/neu proto-oncogene (also called c- erbB2) is located on chromosome 17q11(57 ), which encodes for $\mathrm{p} 185$, a transmembrane glycoprotein with tyrosine kinase - activity that belongs to the family of epidermal growth factor receptors. 5 ,6 HER2/neu protooncogene is amplified and /or over expressed in approximately in $25-30 \%$ of invasive primary breast cancers. $^{6-8}$

An association has been found to exist between amplification and /or overexpression of HER-2/neu and a wide variety of different clinical and pathological features of breast carcinoma that include: large tumour size, high grade, lack of steroid receptor expression, axillary lymph nodes metastasis, advanced stage, early relapse, and reduced overall survival., ${ }^{9,10}$ HER-2/neu receptor has become a target for antibody-based therapy with trastuzumab (Herceptin). The treatment approach stands unique owing to its specificity, only patients with tumours that overexpress HER-2/neu benefit from such therapy. For that reason, the determination of HER-2/neu status in breast cancer is becoming of great interest, and recently this treatment has been shown to improve patient's outcome markedly. ${ }^{11,12}$ Indeed, there is much evidence to 
document the essential role of HER-2/neu as a prognostic marker for the aggressiveness of breast cancer. ${ }^{10}$

A crucial development in the evaluation of breast cancers has been the realization that the presence of hormone (estrogen and progesterone) receptors in tumour tissue correlates well with response to hormone therapy and chemotherapy. ${ }^{13,14}$ Steroid hormones bind with high specificity and affinity to intracellular receptors. The steroid receptors belong to superfamily of proteins whose function is to control the transcription of a repertoire of other cellular genes. ${ }^{15}$ Steroid receptors such as estrogen and progesterone receptors are located in the cell nucleus.

Approximately $30 \%$ of unselected patients with breast cancers will respond to hormone therapy such as oophorectomy (or chemical castration) or tamoxifen treatment. The demonstration that radio labelled estradiol bound to some breast cancer specimens and that this effect was related to response to hormone ablation led to the development of hormone receptor assays directed at identification of patients suitable for hormone therapy. ${ }^{16}$ By assay of estrogen receptor status alone, using the standard radioligand binding assay on tissue cytosol samples, a response is seen in between 50 and $60 \%$ of patients with estrogen receptor- positive tumours, in contrast to a $<10 \%$ response observed in patients with estrogen receptor-negative tumours. ${ }^{17}$ Prediction of response can be further refined by combining Progesterone receptor assay. ${ }^{17}$ Patients with ER-positive PR-positive tumours have a $78 \%$ response, those with ER-positive PRnegative a 34\%response, those with ER-negative PRpositive a $45 \%$ response, and those with ER-negative PRnegative tumours' have a $10 \%$ response. ${ }^{18}$ The present study thus attempted to evaluate various clinicopathological parameters in the mastectomy specimens and to probe for any relation with its immunohistochemical expressions in a hospital based cross sectional observational study in Eastern India.

\section{Materials and Methods}

A hospital based cross-sectional observational study was carried out for a period of one year. All the patients suspected of breast malignancy with age $>25$ years were clinically evaluated by physical examination and by FNAC and were included in the study. Patient undergone any form of adjuvant treatment were excluded from the study. A detailed history of the patient with respect to the onset, duration and rate of growth of the lump, presence of pain, any discharge or retraction of nipple and any other relevant past and family history as well as any history of weight loss was taken. Detailed clinical examination of the breast and the lump was done and presence of any axillary or cervical lymph nodes was also noted.

After clinical examination, tumour size from the mastectomy specimen (Fig. 1) was recorded; number of lymph nodes was noted. The modified radical mastectomy samples after surgical removal, were fixed in formalin ${ }^{19}$ and sent for histopathological examination where tissue processing $^{20,21}$ and staining ${ }^{22}$ with haematoxylin \& eosin was done. (Fig. 2) Post mastectomy grading of the malignant breast lesion was done according to ScarffBloom- Richardson's grading (SBR) system in haematoxylin \& eosin stained slides. Immunostaining of the HER-2 protein, Estrogen receptors \& Progesterone receptors was performed for all specimens. A semi quantitative score was used to record results of Estrogen receptor \& Progesterone receptor staining. ${ }^{23}$ HER-2 was scored from 0 to 3 according to the criteria set by Dako. (Table 1)

Table 1: Grading of the immunohistochemical staining for HER2/neu overexpression

\begin{tabular}{|l|c|c|}
\hline \multicolumn{1}{|c|}{ Staining Pattern } & Score & $\begin{array}{c}\text { HER-2/Neu Protein } \\
\text { Overexpression Assessment }\end{array}$ \\
\hline $\begin{array}{l}\text { No staining is observed or membrane staining is observed in } \\
\text { less than 10\% of the tumour cells }\end{array}$ & $\mathbf{0}$ & Negative \\
\hline $\begin{array}{l}\text { A faint/barely perceptible membrane staining is detected in } \\
\text { more than 10\% of the tumour cells. The cells are only stained in } \\
\text { part of their membrane }\end{array}$ & $\mathbf{1 +}$ & Negative \\
\hline $\begin{array}{l}\text { A weak to moderate complete membrane staining is observed in } \\
\text { more than 10\% of the tumour cells }\end{array}$ & $\mathbf{2 +}$ & Weakly positive \\
\hline $\begin{array}{l}\text { A strong complete membrane staining is observed in more than } \\
30 \% \text { (formerly 10\%) of the tumour cells }\end{array}$ & $\mathbf{3 +}$ & Strongly positive \\
\hline Grading of the immunohistochemical staining for ER/PR overexpression \\
\hline \multicolumn{1}{|c|}{ Score for proportion staining } & \multicolumn{1}{|c|}{ Score for staining intensity } \\
\hline $0=$ No nuclear staining & $0=$ No staining \\
\hline $1=<1 \%$ nuclei staining & $1=$ Weak staining \\
\hline $2=1-10 \%$ nuclei staining & $2=$ Moderate staining \\
\hline $3=11-33 \%$ nuclei staining & $3=$ Strong staining \\
\hline $4=34-66 \%$ nuclei staining & \\
\hline $5=67-100 \%$ nuclei staining & \\
\hline Adding the two scores together gives a maximum score of 8. \\
\hline
\end{tabular}




\section{Statistical Analysis}

Data collected was checked for completeness and then statistically analyzed using descriptive or analytical statistics, whichever applicable. Different levels were expressed at 95\% Confidence Interval. A Pvalue of less than 0.05 was considered statistically significant. All Statistical analysis for various measures was performed using various statistical software packages like Statistical Package for the Social Sciences (Windows version 21.0; SPSS Inc, Chicago [IL], USA) and Microsoft Excel.

\section{Results}

The present study was conducted on histopathological confirmed cases of breast carcinoma patients admitted in a tertiary care teaching hospital in Eastern India for elective mastectomy for Carcinoma breast over a one year period.

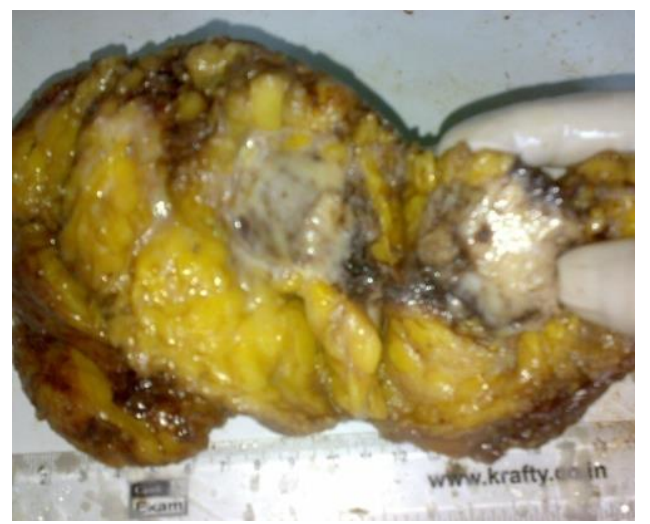

Fig1: Mastectomy specimen showing presence of tumour

The range of patients presenting with breast cancer was between $30-70$ years, while 41 patients were below the age of 50 years and 18 above it. (18.64\%) cases out of 59 were between age group $30-39$ years, 30 cases $(50.85 \%)$ were between $40-49$ years, $14(23.73 \%)$ cases were between 50-59 years and four cases $(6.78 \%)$ were 60 years or above.

$37(62.7 \%$ were in postmenopausal and 22 $(37.33 \%)$ in premenopausal group. So it was concluded that there is increased risk of breast cancer in postmenopausal group. So it was concluded that there is increased risk of breast cancer in lower parity. Having more children is associated with lower risk. $55.94 \%$ observed cases were of T3 (size $>5 \mathrm{~cm}$ ).

Fifty nine formalin fixed and paraffin embedded surgical specimens of different malignant lesions of breast were studied based on histopathological and immunohistochemical findings.

Among the histopathological types of the tumours, IDC NOS constituted 52 cases (88.10\%), Invasive lobular carcinoma constituted, Medullary carcinoma, Invasive Papillary carcinoma and Mucinous carcinoma one case each $(1.70 \%)$, Metaplastic carcinoma three cases $(5.10 \%)$.

14 case $(23.73 \%)$ of Grade I was seen, whereas 32 cases $(54.24 \%)$ belonged to Grade II, and 13 cases (22.03\%) to Grade III. Out of 59 cases lymph node metastases were seen in 35 cases $(59.32 \%)$, and it was absent in 24 cases $(40.68 \%)$. Out of the 59 cases, Stage IA constituted three cases (5.10\%), Stage IIA 11 cases (18.6\%), Stage IIB 15 cases (25.4\%), and Stage IIIA 30 cases $(50.8 \%)$. Various clinical parameters were evaluated. (Table 2). Relation of various clinicopathological parameters in different age groups were probed and analyzed. (Table 3,4 )

Table 2: Evaluation of various clinical parameters

\begin{tabular}{|c|c|}
\hline Parameters & Freq $(\%)$ \\
\hline \multicolumn{2}{|l|}{ Age Group (in years) } \\
\hline $30-39$ & $11(18.64)$ \\
\hline $40-49$ & $30(50.85)$ \\
\hline $50-59$ & $14(23.73)$ \\
\hline 60 and above & $4(6.78)$ \\
\hline \multicolumn{2}{|l|}{ Menopausal Status } \\
\hline Post Menopausal & $37(62.7 \%)$ \\
\hline Pre Menopausal & $22(37.33 \%)$ \\
\hline \multicolumn{2}{|l|}{ Parity Status } \\
\hline Low Parity $(<$ and equal to 2 children $)$ & $31(52.50 \%)$ \\
\hline High Parity(>2 children) & $28(47.50 \%)$ \\
\hline \multicolumn{2}{|l|}{ Tumour Size } \\
\hline$<2 \mathrm{~cm}$ & $3(5.08)$ \\
\hline $2-5 \mathrm{~cm}$ & $23(38.98)$ \\
\hline$>5 \mathrm{~cm}$ & 33 (55.94) \\
\hline \multicolumn{2}{|l|}{ Clinical Staging } \\
\hline IA & $3(5.08)$ \\
\hline IIA & $11(18.64)$ \\
\hline IIB & $15(25.43)$ \\
\hline IIIA & $30(50.85)$ \\
\hline \multicolumn{2}{|l|}{ Grading } \\
\hline $\mathrm{I}$ & $14(23.73)$ \\
\hline II & $32(54.24)$ \\
\hline III & $13(22.03)$ \\
\hline \multicolumn{2}{|l|}{ Histopathological Type } \\
\hline IDC & $52(88.10)$ \\
\hline Invasive Lobular Carcinoma & $1(1.70)$ \\
\hline Medullary Carcinoma & $1(1.70)$ \\
\hline Invasive Papillary Carcinoma & $1(1.70)$ \\
\hline Invasive Mucinous Carcinoma & $1(1.70)$ \\
\hline Metaplastic Carcinoma & $3(5.10)$ \\
\hline \multicolumn{2}{|l|}{ Lymph Node Metastases } \\
\hline Present & $35(59.32)$ \\
\hline Absent & $24(40.68)$ \\
\hline
\end{tabular}


Table 3: Various clinical parameters in different age groups

\begin{tabular}{|c|c|c|c|c|c|}
\hline & \multicolumn{4}{|c|}{ Age Groups } & \multirow{2}{*}{ Significance } \\
\hline & 30-39 Years & 40-49 Years & 50-59 Years & $>60$ Years & \\
\hline \multicolumn{6}{|c|}{ Tumour Size } \\
\hline $\mathrm{T} 1$ & 1 & 1 & 1 & 0 & \multirow{3}{*}{$\mathrm{p}=0.08(>0.05)$} \\
\hline $\mathrm{T} 2$ & 5 & 10 & 7 & 1 & \\
\hline T3 & 5 & 19 & 6 & 3 & \\
\hline \multicolumn{6}{|c|}{ Histopathological Grading } \\
\hline I & $5(8.48 \%)$ & $4(6.78 \%)$ & $3(5.08 \%)$ & $2(3.39 \%)$ & \multirow{3}{*}{$\mathrm{p}=0.30(\mathrm{p}>0.05)$} \\
\hline II & $4(6.78 \%)$ & $19(32.21 \%)$ & $7(11.86 \%)$ & $2(3.39 \%)$ & \\
\hline III & $2(3.39 \%)$ & $7(11.86 \%)$ & $4(6.78 \%)$ & $0(0)$ & \\
\hline \multicolumn{6}{|c|}{ Lymph Node Metastases } \\
\hline Positive & $5(45.45 \%)$ & $20(66.67 \%)$ & $9(64.29 \%)$ & $1(25 \%)$ & \multirow{2}{*}{$\mathrm{p}=0.30(\mathrm{p}>0.05)$} \\
\hline Negative & $6(54.55)$ & $10(33.33)$ & $5(35.71)$ & $3(75 \%)$ & \\
\hline
\end{tabular}

Table 4: Distribution of lymph node metastases

\begin{tabular}{|c|c|c|c|}
\hline & $\begin{array}{l}\text { Positive LN } \\
\text { Metastases }\end{array}$ & $\begin{array}{c}\text { Negative LN } \\
\text { Metastases }\end{array}$ & Significance \\
\hline \multicolumn{4}{|l|}{ Histopathological Type } \\
\hline IDC NOS & 29 & 23 & \\
\hline Invasive Lobular Carcinoma & 1 & 0 & \\
\hline Invasive Papillary Carcinoma & 1 & 0 & \\
\hline Invasive Mucinous Carcinoma & 0 & 1 & \\
\hline Medullary Carcinoma & 1 & 0 & \\
\hline Metaplastic Carcinoma & 3 & 0 & \\
\hline \multicolumn{4}{|l|}{ Histopathological Grading } \\
\hline I & $3(21.42 \%)$ & $11(78.58 \%)$ & \multirow{3}{*}{$\begin{array}{l}\chi^{2}=11.108, \quad \mathrm{df}=2, \\
\mathrm{p}=0.004(\mathrm{p}<0.05)\end{array}$} \\
\hline II & $22(68.75 \%)$ & $10(31.25 \%)$ & \\
\hline III & $10(76.92 \%)$ & $3(23.08 \%)$ & \\
\hline \multicolumn{4}{|l|}{ Tumor Size } \\
\hline T1 & $0(0.0 \%)$ & $3(100 \%)$ & \multirow{3}{*}{$\begin{array}{l}\chi^{2}=6.334, \quad d f=2, \\
p=0.042(p<0.05)\end{array}$} \\
\hline $\mathrm{T} 2$ & $12(52.17 \%)$ & $11(47.82 \%)$ & \\
\hline T3 & $23(69.69 \%)$ & $10(30.31 \%)$ & \\
\hline \multicolumn{4}{|l|}{ Clinical Staging } \\
\hline IA & $0(0.0 \%)$ & $3(100 \%)$ & \multirow{4}{*}{$\begin{array}{l}\chi 2=45.187, d f=3, \\
p=0.001(p<0.05) .\end{array}$} \\
\hline IIA & $0(0.0 \%)$ & $11(100.0 \%)$ & \\
\hline IIB & $5(33.33 \%)$ & $10(66.67 \%)$ & \\
\hline IIIA & $30(100 \%)$ & $0(0.0 \%)$ & \\
\hline
\end{tabular}

Immunohistochemical expressions of various receptors were noted. (Table 5). Relation of immunohistochemical expression with different clinicopathological parameters were observed and analyzed. (Table 6,7).

Table 5: Expressions of various receptors

\begin{tabular}{|l|c|c|c|}
\hline & HER-2/Neu & ER & PR \\
\hline Positive & $27(45.76 \%)$ & $39(66.10 \%)$ & $37(62.71 \%)$ \\
\hline Negative & $32(54.24 \%)$ & $20(33.90 \%)$. & $22(37.29 \%)$ \\
\hline
\end{tabular}

Table 6: Relation of immunohistochemical expression with different clinicopathological parameters

\begin{tabular}{|l|c|c|c|c|c|c|}
\hline $\begin{array}{c}\text { Histopathological } \\
\text { Types }\end{array}$ & $\begin{array}{c}\text { HER2/Neu } \\
\text { Expression } \\
\text { Negative }\end{array}$ & $\begin{array}{c}\text { HER2/Neu } \\
\text { Expression } \\
\text { Positive }\end{array}$ & $\begin{array}{c}\text { ER } \\
\text { Expression } \\
\text { Positive }\end{array}$ & $\begin{array}{c}\text { ER } \\
\text { Expression } \\
\text { Negative }\end{array}$ & $\begin{array}{c}\text { PR } \\
\text { Expression } \\
\text { Negative }\end{array}$ & $\begin{array}{c}\text { PR } \\
\text { Expression } \\
\text { Positive }\end{array}$ \\
\hline IDC & 25 & 27 & 36 & 16 & 18 & 34 \\
\hline ILC & 1 & 0 & 1 & 0 & 0 & 1 \\
\hline Medullary & 1 & 0 & 0 & 1 & 1 & 0 \\
\hline Metaplastic & 3 & 0 & 0 & 3 & 3 & 0 \\
\hline Mucinous CA & 1 & 0 & 1 & 0 & 0 & 1 \\
\hline Papillary & 1 & 0 & 1 & 0 & 0 & 1 \\
\hline
\end{tabular}




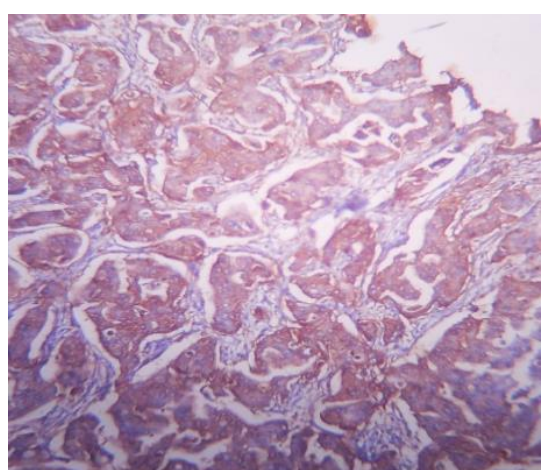

Fig 2(A): HER-2/neu-- 3+ (100X) showing complete membrane staining in more than $30 \%$ tumour cells

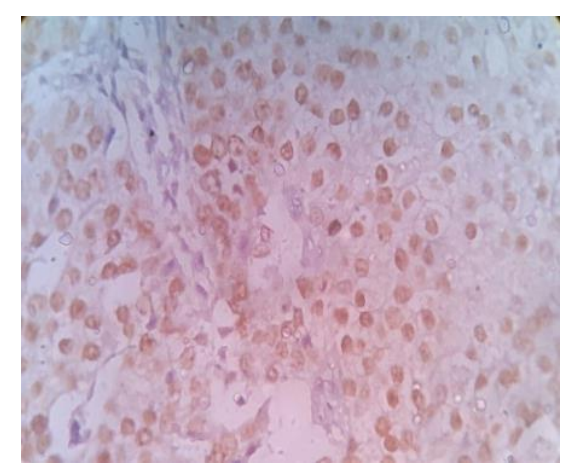

Fig. 2(B): ER positive IDC (400X)

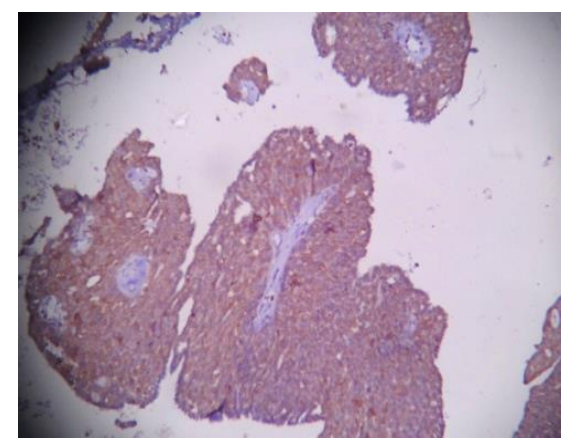

Fig. 2(C): PR positive invasive papillary carcinoma (100X) 
Table 7: Presentations of clinicopathological parameters with various immunohistochemical expression

\begin{tabular}{|c|c|c|c|c|c|c|c|c|c|}
\hline & Her2/Neu -ve & Her2/Neu +ve & Sig & ER +ve & ER -ve & Sig & PR -ve & PR +ve & Sig \\
\hline \multicolumn{10}{|l|}{ Age Category } \\
\hline $\mathrm{A}(30-39$ yrs $)$ & $3(27.27 \%)$ & $8(72.73 \%)$ & \multirow{4}{*}{$\begin{array}{l}\chi 2=8.481(\mathrm{df}=3) \\
, p=0.037\end{array}$} & $5(45.45 \%)$ & $6(54.55 \%)$ & \multirow{4}{*}{$\begin{array}{l}\chi^{2}=4.368(\mathrm{df}=3) \\
\mathrm{p}=0.224\end{array}$} & $5(45.45 \%)$ & $6(54.55 \%)$ & \multirow{4}{*}{$\begin{array}{c}\chi^{2}=0.592(\mathrm{df}=3) \\
\mathrm{p}=0.898\end{array}$} \\
\hline $\mathrm{B}(40-49 \mathrm{yrs})$ & $15(50.00 \%)$ & $15(50.00 \%)$ & & $21(70 \%)$ & $9(30 \%)$ & & $11(36.67 \%)$ & $19(63.33 \%)$ & \\
\hline $\mathrm{C}(50-59 \mathrm{yrs})$ & $10(71.43 \%)$ & $4(28.57 \%)$ & & $9(64.29 \%)$ & $5(35.71 \%)$ & & $5(35.71 \%)$ & $9(64.29 \%)$ & \\
\hline $\begin{array}{l}\mathrm{D}(60 \text { and } \\
\text { above })\end{array}$ & $4(100 \%)$ & 0 & & $4(100 \%)$ & $0(0.00 \%)$ & & $1(25 \%)$ & $3(75 \%)$ & \\
\hline \multicolumn{10}{|c|}{ Clinical Staging } \\
\hline IA & $2(66.67 \%)$ & $1(33.33 \%)$ & \multirow{4}{*}{$\begin{array}{l}\chi^{2}=8.06(\mathrm{df}=3) \\
\mathrm{p}=0.045\end{array}$} & $1(33.33 \%)$ & $2(66.67 \%)$ & \multirow{4}{*}{$\begin{array}{l}\chi^{2}=8.273(\mathrm{df}=3) \\
\mathrm{p}=0.041\end{array}$} & $2(66.67 \%)$ & $1(33.33 \%)$ & \multirow{4}{*}{$\begin{array}{c}\chi^{2}=8.823(\mathrm{df}=3), \\
p=0.032\end{array}$} \\
\hline IIA & $10(90.91 \%)$ & $1(9.09 \%)$ & & $11(100 \%)$ & $0(0 \%)$ & & $0(0 \%)$ & $11(100 \%)$ & \\
\hline IIB & $6(40 \%)$ & $9(60 \%)$ & & $10(66.67 \%)$ & $5(33.33 \%)$ & & $6(40 \%)$ & $9(60 \%)$ & \\
\hline IIIA & $14(46.67 \%)$ & $16(53.33 \%)$ & & $17(23.33 \%)$ & $13(76.67 \%)$ & & $14(46.67 \%)$ & $16(53.33 \%)$ & \\
\hline \multicolumn{10}{|l|}{ Tumour Size } \\
\hline T1 & $2(66.67 \%)$ & $1(33.33 \%)$ & \multirow{3}{*}{$\begin{array}{l}\chi^{2}=2.329( \\
\mathrm{df}=2), \mathrm{p}=0.312\end{array}$} & $1(11.90 \%)$ & $2(88.10 \%)$ & \multirow{3}{*}{$\begin{array}{l}\chi^{2}=1.636(\mathrm{df}=2) \\
\mathrm{p}=0.441\end{array}$} & $2(66.67 \%)$ & $1(33.33 \%)$ & \multirow{3}{*}{$\begin{array}{c}\chi 2=1.181(\mathrm{df}=2) \\
\mathrm{p}=0.554\end{array}$} \\
\hline $\mathrm{T} 2$ & $15(65.22 \%)$ & $8(34.78 \%)$ & & $16(69.57 \%)$ & $7(30.43 \%)$ & & $8(34.78 \%)$ & $15(65.22 \%)$ & \\
\hline $\mathrm{T} 3$ & $15(45.45 \%)$ & $18(54.55 \%)$ & & $22(66.67 \%)$ & $11(33.33 \%)$ & & $12(36.36 \%)$ & $21(63.64 \%)$ & \\
\hline \multicolumn{10}{|c|}{ Histopathological Grade } \\
\hline $\mathrm{I}$ & $10(71.43 \%)$ & $4(28.57 \%)$ & \multirow{3}{*}{$\begin{array}{l}\chi^{2}=4.604(\mathrm{df}=2) \\
\mathrm{p}=0.100\end{array}$} & $12(85.71 \%)$ & $2(14.29 \%)$ & \multirow{3}{*}{$\begin{array}{l}\chi^{2}=14.274 \\
(\mathrm{df}=2), \mathrm{p}=0.001\end{array}$} & $3(21.43 \%)$ & $11(78.57 \%)$ & \multirow{3}{*}{$\begin{array}{c}\chi^{2}=11.388(\mathrm{df}=2), \\
\mathrm{p}=0.003\end{array}$} \\
\hline II & $18(56.25 \%)$ & $14(43.75 \%)$ & & $24(75 \%)$ & $8(25 \%)$ & & $9(28.12 \%)$ & $23(71.88 \%)$ & \\
\hline III & $4(30.77 \%)$ & $9(69.23 \%)$ & & $3(23.08 \%)$ & $10(76.92 \%)$ & & $10(76.92 \%)$ & $3(23.08 \%)$ & \\
\hline \multicolumn{10}{|c|}{ Lymph Node Metastases } \\
\hline Positive & $16(45.71 \%)$ & $19(54.29 \%)$ & \multirow{2}{*}{$\begin{array}{l}\chi 2=2.518(\mathrm{df}=1) \\
, \mathrm{p}=0.113\end{array}$} & $19(25.71 \%)$ & $16(74.29 \%)$ & \multirow{2}{*}{$\begin{array}{l}\chi 2=5.361 \\
(\mathrm{df}=1), \mathrm{p}=0.021\end{array}$} & $5(20.88 \%)$ & $19(79.12 \%)$ & \multirow{2}{*}{$\begin{array}{c}\chi^{2}=4.684 ;(\mathrm{df}=1) \\
\mathrm{p}=0.030\end{array}$} \\
\hline Negative & $16(66.67 \%)$ & $8(33.33 \%)$ & & $20(83.33 \%)$ & $4(16.67 \%)$ & & $17(48.57 \%)$ & $18(51.43 \%)$ & \\
\hline
\end{tabular}

Table 8: Comparative Evaluation of Her-2/Neu overexpression with ER status

\begin{tabular}{|l|c|c|c|c|}
\hline & $\begin{array}{c}\text { No. of ER-Ve } \\
\text { Cases }\end{array}$ & $\begin{array}{c}\text { No. of ER } \\
\text { +Ve Cases }\end{array}$ & Total & Significance \\
\cline { 1 - 4 } No. of Her2/Neu -Ve Cases & 6 & 26 & 32 & \multirow{2}{*}{$\chi 2=7.161$} \\
No. of Her2/Neu +Ve Cases & 14 & 13 & 27 & $\mathrm{df}=1$ \\
Total & 20 & 39 & 59 & $\mathrm{p}=0.007$ \\
\hline
\end{tabular}


ER negative cases were comparatively higher in HER-2/neu positive cases and vice-versa and these differences are statistically significant. (Table 8) PR negative cases were comparatively higher in HER-2/neu positive cases and vice-versa and these differences are statistically significant. (Table 9)

Table 9: Comparative evaluation of her-2/neu overexpression with PR status

\begin{tabular}{|l|c|c|c|c|}
\hline & $\begin{array}{c}\text { No. of PR- } \\
\text { Ve Cases }\end{array}$ & $\begin{array}{c}\text { No. of PR } \\
\text { +Ve Cases }\end{array}$ & Total & Significance \\
\cline { 1 - 4 } No. of Her2/Neu -Ve Cases & 7 & 25 & 32 & \multirow{2}{*}{$\chi 2=7.104$} \\
No.of Her2/Neu+Ve Cases & 15 & 12 & 27 & $\mathrm{df}=1$ \\
\cline { 1 - 4 } Total & 22 & 37 & 59 & $\mathrm{p}=0.008$ \\
\hline
\end{tabular}

\section{Discussion}

Although the incidence of breast cancer is increasing, it has been possible to decrease the mortality rates mainly because of earlier detection and improvements in adjuvant systemic therapy. Unfortunately, the anti neoplastic agents are associated with substantial morbidity and hence attempts to individualize treatment studies are desirable. Herein lies the importance of the search for the tumour markers which are described in various studies. ${ }^{24}$ Among the various prognostic and predictive factors of breast cancer, ${ }^{25}$ the most widely studied biomarker is the human epidermal growth factor receptor 2 (HER2) gene, also referred to as $E R B B 2$ or $H E R 2 / n e u$, which is amplified in approximately 18-20 per cent of all breast cancers. ${ }^{26}$ Amplification of this gene is associated with the rapid progression of the disease, increased metastatic potential, increased resistance to tamoxifen and better response to anthracycline-based chemotherapy. The discovery of targeted therapy against the HER2 gene in the form of the humanized anti-HER2 monoclonal antibody trastuzumab (Herceptin, Genentech, South San Francisco, CA) and HER1/HER2 dual receptor inhibitor, lapatinib, has brought forward an effective treatment modality for patients having the gene amplification. ${ }^{27}$ Among the hormone receptors, it can be said that expression of ER in breast tumour might indicate the hormonal dependence and will regress with appropriate endocrine manipulation ${ }^{[28]}$ and assessment of PR should assist in predicting response to hormonal therapy more accurately.

In the present study, 59 formalin fixed and paraffin embedded surgical specimens of invasive breast carcinoma were evaluated for ER, PR expression and HER-2/neu protein overexpression by applying immunohistochemical stain using antibody for ER,PR and HER-2/neu and were compared with clinicopathological parameters like age, tumour size, histopathological grades, lymph node metastases, skin involvement and surgical staging. Out of the 59 cases, maximum patients were in the age group of 40-49 years $(50.85 \%)$. This is in accordance with the study conducted by Hussian M A et al (1994), ${ }^{29}$ who found the peak incidence between age range 41-50 years. Poonam Panjwani et al (2010) ${ }^{30}$ also found most of the cases below 50 years. Out of the 59 cases, 37 cases
$(62.70 \%)$ were of postmenopausal age group that is more than equal to 45 years, 22 cases $(37.30 \%)$ were of premenopausal age group, and this implies that breast cancer risk increases in postmenopausal age group. This is in accordance with the study conducted by Ma et al $2014^{31}$ who found $54.15 \%$ cases in postmenopausal age group and $45.85 \%$ cases in premenopausal age group. Out of the 59 cases, 31 cases $(52.50 \%)$ were seen in those with low parity that is having less than or equal to two children and 28 cases ( $47.50 \%$ ) were of high parity, having more than two children. Similar findings were seen in the study conducted by Lambe $\mathrm{M}$ et al $1996 .{ }^{32}$

In our study, IDC NOS constituted the bulk of the histopathological types $(88.13 \%)$, three cases of metaplastic carcinoma and one case each of invasive lobular, medullary carcinoma, invasive papillary and mucinous carcinoma. This is in accordance with the study conducted by M.I.Perez et $\mathrm{al}^{33}$ who found most of the cases belonging to infiltrating ductal carcinoma (96.3\%). Similar findings were observed by Berg and Hutter $1995 .^{3}$ According to them, the most common type of carcinoma was infiltrative ductal carcinoma (70\%) followed by other different types. Hussain M A et $\mathrm{al}^{29}$ also noted that among the epithelial tumours, invasive ductal carcinoma was the predominant subtype. Grading of 59 cases was done and seen that 32 cases (54.24\%) belonged to Grade II. Similar findings were noted by Zubair Ahmad et al, ${ }^{34} 2009$ who found maximum number of cases, $75.83 \%$ belonged to Grade II. Similar findings were seen in the study done by Le Doussal et al, ${ }^{35} 1989$. Regarding tumour size, maximum number of cases found to be of more than $5 \mathrm{~cm}$ $(55.94 \%)$ and between $2-5 \mathrm{~cm}(38.98 \%)$. This is in accordance with the findings of Saleh et $\mathrm{al}^{36}$ who reported $53.6 \%$ and $31.3 \%$ cases of tumour size $(2-5 \mathrm{~cm}$ and $>5 \mathrm{~cm}$ ) respectively.

Lymph node metastases were seen in 35 cases (59.32\%), and it was absent in 24 cases $(40.68 \%)$. Our study closely matched the study conducted by Esraa Abdul-Aal Salman Al-Dujaily, 2008, ${ }^{37}$ who found lymph node metastases were positive in $69.4 \%$ cases and negative in $30.6 \%$ cases. Aziz et al., 2001 ${ }^{38}$ observed positive axillary lymph node status in (54\%), while negative axillary lymph node status in $(46 \%)$. In the present study, $50.85 \%$ of the cases belonged to Stage III while $25.43 \%$ to Stage IIB, This is in accordance to the study conducted by Esraa Abdul- 
Aal Salman Al-Dujaily, 2008, ${ }^{37}$ who found that $56.9 \%$ were of stage III and stage II constituted $31.9 \%$ of the cases. Similar findings were seen in the study done by Aziz et al., 2001. ${ }^{38}$

In our study, out of 59 cases, maximum cases were of T3 which was most common among 40-49 years but there was no direct linear correlation with stage and age. Grading of 59 cases was done and it was seen that maximum cases were of Grade II which was most common among 40-49 years (32.21\%). Out of 59 cases, lymph node metastases were seen in 35 cases $(59.32 \%)$, and were most common among 40-49 years $(66.67 \%)$. Above findings concluded that age has independent prognostic value and there was no direct association of age with other prognostic markers. Similar finding was shown by Abner AL, 1998. 39,40

Out of 59 cases of IDC NOS cases, percentage of lymph node metastases was $55.76 \%$ which implies that maximum cases of lymph node metastasis was seen in IDC NOS and was statistically significant which was at par with study done by Amrut V. Ashturkar, ${ }^{41} 2011$ who also found that maximum lymph node metastasis $68(71.57 \%)$ cases seen were from infiltrating duct carcinoma (IDC). Maximum number of lymph node metastasis was seen among T3 (69.69\%). It was concluded that lymph node metastasis increases with larger tumour size and this finding was statistically significant. This was at par with the findings in the study done by Christine L. Carte, $1988^{42}$ who found that tumours that are less than $3 \mathrm{~cm}$ involved one to three nodes whereas tumours greater than $3 \mathrm{~cm}$ involved 4 or more nodes. Maximum number of lymph node metastasis was seen in Grade III followed by Grade II and Grade I, implying that lymph node metastasis increases with higher grades and this finding was statistically significant, which was at par with study conducted by Amrut V. Ashturkar, 2011. ${ }^{41}$ Out of 59 cases 30 cases were in stage IIIA and all were positive for lymph node metastasis implying that stage IIIA associated with maximum lymph node metastasis which was at par with study done by Voss M , 1999. ${ }^{43}$

Among 59 cases, ER was positive in 39 cases (66.10\%), PR was positive in 37 cases $(62.71 \%)$ and HER-2/neu was positive in 27 cases (45.76\%). Similar findings were seen in the study done by Panjwani $\mathrm{P}$ et al in $2010 . .^{30}$ Our findings showed higher HER-2/neu values than those reported by Marc J. et al., $1988^{44}$ and Yamashita et al 2004, ${ }^{45}(14.5 \%$ and $20.1 \%)$ respectively. Ariga R in $2005^{46}$ observed $22 \%$ cases of breast cancer patients showed HER-2/neu positivity.

In our study, the maximum percentage of HER2/NEU positive cases was in the age range of 30-39 years followed by 40-49 and further higher age group. These findings suggest that HER-2/neu expression declines with age and was statistically significant. This is in accordance with what is reported in literature that Her2/neu expression declines with age, EppenbergerCastori S.2001. ${ }^{47}$ According to Naqvi SQH, 2007, ${ }^{48}$
$53 \%$ of the cases below 40 years and $47 \%$ of the cases above 40 years had HER-2/neu over expression. Chauhan $\mathrm{N}$ in $2010^{49}$ also concluded from her study that HER-2/neu over expression is seen comparatively more in younger patients. Regarding tumour size, we did not found a significant association between increased tumour size and HER-2/neu over expression which is in concordance with study conducted by Esraa Abdul-Aal Salman Al-Dujaily, 2008. ${ }^{37}$

In our study of 59 cases maximum HER-2/neu positivity was seen among grade III $(69.23 \%)$ followed by II and I. This study showed that HER-2/NEU expression increases with higher grades but did not show any significant association. Our finding was at par with study done by Al-Moundhri et al., (2003), ${ }^{50}$ Almasri et al., (2005). ${ }^{51}$ However Saleh et al., 2007, ${ }^{36}$ showed that grade II and III tumours predominantly (92.9\% and $87.7 \%$, respectively) over expressed HER$2 /$ neu with significant difference $(\mathrm{P}<0.0001)$.

Out of the 35 cases with lymph node metastases, 19 cases (54.29\%) showed HER-2/neu positivity, on the other hand only eight cases (33.33\%) showed HER$2 /$ neu positivity out of the 24 cases without lymph node metastases. We couldnot find any significant association between HER-2/neu overexpression and lymph node metastases. This finding was consistent with results of Marc J. et al., $1988^{44}$ and Esraa AbdulAal Salman Al-Dujaily, 2008. ${ }^{37}$ However study done by Aziz et al., 2001, ${ }^{38}$ showed a strong correlation between HER-2/neu overexpression and axillary lymph nodes metastases.

Out of the 27 cases positive for HER-2/neu, maximum number of cases was from stage IIB $(60 \%)$, on the other hand out of 32 negative cases for HER$2 /$ neu, most of cases was from stage IIA(90.91). Hence we found a significant association between HER-2/neu overexpression and staging. Our finding is supported by the study of Almasri et al., 2005. ${ }^{51}$ In contrast, Aziz et al., ${ }^{38} 2001$ and Esraa Abdul-Aal Salman Al-Dujaily, $2008^{37}$ did not find any association between HER-2/neu overexpression and staging.

The total number of ER positive cases was $39(66.10 \%)$ and that of negative cases was 20(33.90\%). While, the total number of PR positive cases were $37(62.71 \%)$ and that of negative cases were 22(37.28\%). Similar results shown in study done by Mohammad Faheem et al $^{52}$ 2012. S.B.Deasi et al in $2000^{53}$ showed that in contrast to the higher rates reported in Western literature, only $32.6 \%$ and $46.1 \%$ of the tumours were positive for ER and PR respectively. Our findings are also in accordance with the study of Lakmini K.B.Mudduwa, $2009^{54}$ who studied 151 breast cancer specimens and found ER was negative in $54.3 \%$ of the cases and PR was negative in $51.7 \%$ cases.

In our study maximum ER and PR positive cases were among 40-49 yrs and we could not find any statistically significant association between age 
distribution and Hormone receptor expression. Our results are consistent with the findings of E. Ur Rahman $2011^{55}$ who did not find any association between age distribution and hormone receptor expression.

We also did not find any significant association between tumour size and ER \& PR expression. Our findings are supported by the study conducted by E. Ur $\operatorname{Rahman}(2011)^{55}$ but Lucia A et al $(2001)^{56}$ found a significant association between ER,PR expression and tumour size.

Out of the 39 ER positive cases, 36 cases $(69.23 \%)$ were IDC NOS, and out of 37 PR positive cases, 34 cases $(65.38 \%)$ were IDC NOS, rest cases being Invasive lobular carcinoma, Papillary and Mucinous carcinoma which was positive for both ER and PR positive. Our findings closely matched with that of Chauhan $\mathrm{N}$ in $2010^{49}$ who found Papillary carcinoma, Mucinous carcinoma has higher rates of ER \& PR positivity, while Medullary carcinoma cases were typically negative for Hormone receptor expression. Out of the 39 ER positive cases, maximum ER expression seen among Grade I (85.71\%). Out of the 37 PR positive cases, maximum PR expression seen among Grade I (78.57\%). Hence our study showed a significant inverse association between tumour grades and ER \& PR expression. Our findings are in accordance with that of Lucia A et al $2001^{56}$ who observed that lower histopathological grades have statistically more ER \& PR expression. Tero A. H. Jarvinen et al $2000,{ }^{57}$ also noted that hormone receptor expression decreases with higher tumour grades. Chandra N, 2010 49 also found similar results.

Out of the 35 cases positive for Lymph node metastases, 19 cases $(25.71 \%)$ showed ER positivity, while out of the 24 cases negative for Lymph node metastases 20 cases $(83.33 \%)$ showed ER positivity and therefore we found a significant inverse association between ER expression and lymph node metastases. Out of the 35 cases positive for Lymph node metastases, 18 cases $(51.43 \%)$ showed PR positivity, while out of the 24 cases negative for Lymph node metastases, 19 cases $(79.12 \%)$ showed PR positivity. Hence we found a significant inverse association between hormone receptor expression and lymph node metastases. Similar findings was shown by Mohammad Faheem et al 2012. ${ }^{52}$ In our study maximum cases was in stage IIIA, out of which PR positive cases were $53.33 \%$ and ER positive cases were $56.66 \%$ and significant inverse correlation between stage and ER , PR expression was found. Similar results shown by Carol A. Parise 2014. ${ }^{58}$

The results of the present study relating the evaluation of the hormonal receptors and Her-2.neu overxpression with various clinicopathological parameters suggest that HER-2/neu overexpression is associated significantly with adverse prognostic factors like young age, lymph node metastases, higher grade, and higher clinical staging. These findings match with the majority of studies done till date.

\section{Conclusion}

The present study showed a significant inverse association between ER and PR expression and higher tumour grades, axillary lymph node metastases and stage. HER-2/neu overexpression is significantly associated with clinicopathlogical parameters like younger age group, increased tumour size, higher tumour grades, and higher clinical staging. No significant association was found between ER \& PR expression and the rest of the clinicopathological parameters. Significant association was seen between tumour size and lymph node metastases implying that lymph node metastasis increases with larger tumour size. Lymph node metastasis increases with higher stage and this finding was statistically significant.

Funding: No funding sources.

Conflict of interest: None declared.

\section{References}

1. Bray F, Ferlay F, Pisani P, Parkin DM. Cancer burden in the year 2000 the global picture. Eur J Cancer 2001;37:S4-66.

2. Breast cancer statistics. Accessed from https://www.wcrf.org/int/cancer-facts-figures/dataspecific-cancers/breast-cancer-statistics Accessed on August 01, 2018

3. . World Cancer Report 2014. Accessed from http://www.who.int/cancer/publications/WRC_2014/en/ Accessed on August 01, 2018

4. Berg JW, Hutter R VP. Breast cancer. Cancer 1995;75:257-69.

5. Mona MR, Noha MR, Manal KG. The association of HER-2/neu overexpression In Relation with P53 Nuclear Accumulation, Hormonal Receptor Status and common clinicopathological prognostic parameters in a series of Egyptian women with invasive ductal carcinoma. Eur $J$ Med 2007;(4):73-9.

6. Hung MC, Lau YK. Basic science of HER-2/neu. Are view. Sem Oncol 1999;12:51-9.

7. Coussens L, Yang-Feng TL, Lioa YC, Chen Eea. Tyrosine kinase receptor with extensive homology to EGF receptor shares chromosomal location with neu oncogene. Sci 1985;230:1132-1139.

8. Schecter AL, Stern DF, Vaidyanathan L, Decker SJ, Drebin JA, Greene MI, et al. The neu oncogene:An erbBrelated gene encoding a 185,000- Mr tumour antigen. Nature 1984;312:513-16.

9. Slamon DJ, Goldolphin W, Jones LA. Studies of the HER-2/proto-oncogene in human breast cancer and ovarian cancer. Sci 1989;44:707-12.

10. Anwar N, Mokhtar N, Mourad M et al. cerbB2 and its relation to lymph node positivity: Short term follow-up in Egyptian cancer patients. CMB 1994;1:325-29.

11. Robbins P. The P53 tumour supressor gene and the cerbB and c-erbB2/HER2 oncogene in breast cancer. In Application of molecular biology to diagnostic pathology, International Congress of the International Academy of Pathology; 1994; Hong Kong. p. 452-460

12. Trastuzumab for the adjuvant treatment of early-stage HER2-positive breast cancer. National Institute for 
Health and Clinical Excellence(NICE). 2006:1 August; p. 119-125.

13. Kroese M, Zimmern RL, Pinder SE. HER2 status in breast cancer-an example of pharmacogenetic testing. $J$ Royal Soc Med 2007;100(7):326-29.

14. Barnes DM, Hanby AM. Oestrogen and progeterone receptors in breast cancer: past, present and future. Histopathol 2001;38:271-74.

15. Hawkins RA, Roberts MM, Forrest AM. Oestrogen receptors and breast cancer. Current status. Br J Surg 1980;67:162-65.

16. Parker MG. Nuclear horomne receptors. In; 1991; London: Academic Press.

17. Jensen EV, Jacobson HI. Buyers guide to the mechanism of oetrogen action. Recent Prog Horm Res 1962;18:387

18. NIH consensus development conference on steroid receptors in breast cancer. Cancer 1980;46:2759-963

19. Graham A. Risk Factors for Breast Cancer according to Estrogen and Progesterone Receptor Status. JNCI 2003 April; 96.

20. Rosai J. Appendices. In Rosai and Ackerman's Surgical Pathology. 9th ed.: ELSEVIER; 2009. p. 2921-2923.

21. Lena T, Spencer, Bancroft JD. Tissue processing. In Bancroft JD, Gamble M. Theory and Practice Of Histological Techniques. 6th ed.: Churchill Livingstone Elsevier; 2008. p. 84-87.

22. Lena T, Spencer, Bancroft JD. Microtomy:Paraffin and Frozen. In Bancroft JD, Gamble M. Theory and Practice Of Histological Techniques. 6th ed.: Churchill Livingstone Elsevier; 2008. p. 93.

23. Gamble M. The Haematoxylins and Eosin. In Bancroft JD, Gamble M. Theory and Practice of Histological Techniques. 6th ed.: Churchill Livingstone Elsevier; 2008. p. 126-127

24. Leake R, Barnes D, Pinder S, Ellis I, Anderson L, Anderson T, et al. Immunohistochemical detection of steroid recepors in breast cancer: a working protocol. $J$ Clin Pathol 2000;53:634-35.

25. Schiller AB, Clark WS, Cotsonis G, Lawson D. Image cytometric bcl-2:bax and bcl-2:bcl-x ratios in breast carcinoma:correlation with prognosis. Cytometry 2002;50(4):203-9122.

26. Walker RA. Use and assessment of diagnostic and predictive markers in breast pathology. Curr Diagn Pathol 2007;13:126-34.

27. Koeppen HK, Wright BD, Burt AD, Quirke P, McNicol $\mathrm{AM}$, Dybdal NO et al. Overexpression of HER-2/neu in solid tumour: an immunohistochemical survey. Histpathol 2001:96-104.

28. Slamon DJ, Leyland-Jones B, Shak S, Fuchs H, Paton V, Bajamonde A, et al. Use of chemotherapy plus a monoclonal antibody against HER2 for metatstatic breast cancer that overexpresses HER2. $N$ Engl J Med 2001;344:783-92.

29. Jensen EV, Desombre ER, Jungblot PW, Jensen EV, Desombre ER, Jungblot PW. Estrogen receptor in hormone responsive tissue and in endocrine tumour influencing host tumour balance. 1967;15-30

30. Hussain MA, Ali S, Tyagi SP, Reza H. Incidence of breast cancer at Aligarh. J Indian Med Assoc 1994;92(9):296-97.

31. Panjwani P, Epari S, Karpate A, Shrisat H, Rajshekharan $\mathrm{P}$, Basak R, et al. Assessment of HER-2/neu status in breast cancer using fluorescence in situ hybridization \& immunohistochemistry: Experience of a tertiary cancer referral centre in India. Indian J Med Res 2010;132:287294.
32. Ma F-J, Liu Z-B, Hu X, Ling H, Li S, et al. Prognostic Value of Myeloid Differentiation Primary Response and Toll-Like Receptor 4 in Breast Cancer Patients. PLoS ONE 2014; 9(10): e111639. doi:10.1371/journal.pone.0111639.

33. Lambe M, Hsieh CC, Chan HW, Ekbom A, Trichopoulos D, Adami HO. Breast Cancer Res Treat 1996;38(3):30511.

34. Perez MI, Picon G, Ugalde J. Her-2/neu in breast cancer patients.immunohistochemical comparison with monoclonal and polyclonal antibodies.amplification with chromogen in situ hybridization(cish). In instituto del cancer.solca.cuenca; ecuador.

35. Ahmad Z, Khurshid A, Quereshi A, Idress R, Asghar N, Kayani N. Breast carcinoma grading, estimation of tumour size, axillary lymph node status, staging, and nottingham prognostic index scoring on mastectomy specimens. Indian J Pathol Microbiol 2009;52(4):477-81.

36. Le Doussal V, Tubiana-Hulin M, Hacene K, Friedman S, Brunet M. Nuclear characteristics as indicators of prognosis in node negative breast cancer patients. Breast Cancer Res Treatment 1989;14(2):207-16.

37. Saleh F, Abdeen S. Pathobiological features of breast tumours in the State of Kuwait: a comprehensive analysis. Department of Pathology, Faculty of Medicine, Health Science Centre, Kuwait University, Safat, Kuwait. J Carcinogenesis by Pubmed. 2007; 10: p. 1186/1477.

38. Al-Dujaily ES. Pathological Study of Breast Cancer By Application of Epidermal Growth Factor Receptor Type II(HER-2/neu) (Immunohistochemical study) a thesis. 2008 .

39. Aziz SA, Pervez S, Khan S, et al. Significance of immunohistochemical c-erbB2 product localization pattern for prognosis in human breast cancer. Pathol Oncol Res 2001; 7.

40. Kollias J, Elston CW, Ellis IO, et al. Early-onset breast cancer-histopathological and prognostic considerations. Br J Cancer 1997;75:1318-23.

41. Gillet D, Kennedy C, Carmalt H. Breast cancer in young women. Aust NZ J Surg 1997;67:761-64

42. Amrut V. Ashturkar, Gayatri S. Pathak. Factors Predicting the Axillary Lymph Node Metastasis in Breast Cancer: Is Axillary Node Clearance Indicated in Every Breast Cancer Patient? Indian J Surg 2011;73(5):331-35.

43. Carter CL, Allen C, Henson DE. Relation of tumors size, lymph node status and survival in 24,740 breast cancer cases. Cancer 1989;63:181-87.

44. Voss M, Schneider JW. Axillary lymph node involvement in stage III breast cancer: treatment implications. J Surg Oncol 1999;71(3):162-66.

45. Marc J, Johannes LP, Wolter JM, Van DV, et al. Neu protein overexpression in breast cancer: Association with comedo-type ductal carcinoma in situ and limited prognostic value in stage II breast cancer. $N$ Engl J Med 1988;319:1239-45.

46. Yamashita H, Nishio M, Toyama T, Sugiura H, Zhang Z, Kobayashi S, et al. Breast and Endocrine Surgery, Nagoya City University Hospital, Nagoya, Japan. Breast Cancer Res 2004;10:186/738.

47. Ariga R, Zarif A, Korasick J, Reddy V, Siziopikou K, Gattuso P. Correlation of HER-2/neu gene amplification with other prognostic and predictive factors in female breast carcinoma. Breast J 2005;11:278-80.

48. Eppenberger-Castori S, Kueng W, Benz C, Caduff R, Varga Z, Bannwart F, et al. Prognostic and Predictive Significance of ErbB-2 Breast Tumour Levels Measured by Enzyme Immunoassay. J Clin Oncol 2001 by American Society of Clinical Oncology; 19: p. 645-656. 
49. Naqvi S QH, Jamal Q, Mahmood RK, Zaidi S MH, Abbas F. Significance of HER-2/neu oncporotein overexpression on node positive invasive breast cancer. $J$ Coll Phys Surg Pak 2002;12:534-37.

50. Chauhan N. Comparative evaluation of HER-2/neu with hormone receptors and other prognostic parameters in carcinoma breast, B.R.D Medical College, D.D.U. Gorakhpur University, Gorakhpur. Thesis report for doctor of Medicine (Pathology). 2011.

51. A-Moundhri M, Nirmala V, Al-Mawaly K, Ganguly S, Burney I, Rizvi A et al. Significance of P53.Bcl2, and HER-2/neu protein expression in Omani arab females with breast cancer. Pathol Oncol 2003;9:226-31.

52. Almasri NM, Al Hamad M. Immunohistochemical evaluation of human epidermal growth factor receptor 2 and estrogen and progesterone receptors in breast carcinoma in Jordan. Breast Cancer Res 2005;7:1200.

53. Mohammad Faheem, ecancer 6283

54. Desai SB, Moonim MT, Gill AK, Punia RS, Chinoy RF. Hormone receptor status of breast cancer in India: A study of 798 tumours. The Breast 2000;9(5):267-70.

55. Mudduwa LB. Quick score of hormone receptor status of breast carcinoma: Correlation with other clinicopathologic prognostic parameters. IJPM 2009;53(2):159-64.
56. Rahman EU, Shaharyar A, Haafeez M, Goraya AW. Relationship of ER, PR, and HER2-neu status with age, menopausal status, and axillary nodal status in early breast cancer. J Clin Oncol 2011;29(suppl abstr e 11011). 299.

57. Lucia A, Eisenberg A, Koifman S, Magalhaes LM, Rezende Cd. Hormone Receptors: Association With Prognostic Factors For Breast Cancer. Revista Brasilira de Cancerologia. 2001;47(1):49-58.

58. Jarvinen TH, Pelto-Huikko M, Holli K, Isola J. Estrogen Receptor $\beta$ Is Coexpressed with ER $\alpha$ and PR and Associated with Nodal Status, Grade, and Proliferation Rate in Breast Cancer. Am J Pathol 2000;156(1):29-35.

59. Parise CA, Caggiano V. Breast Cancer Survival Defined by the ER/PR/HER2 Subtypes and a Surrogate Classification according to Tumor Grade and Immunohistochemical Biomarkers. J Cancer Epidemiol 2014;2014:469251. doi:10.1155/2014/469251.

How to cite this article: Mukherjee M., Konar K., Bandopadhyay A., Mukherjee S., Era N. Evaluation of clinicopathological parameters and its relation with immunohistochemical expressions in breast carcinoma: A hospital based cross-sectional observational study. $J$ Diagn Pathol Oncol 2018;3(4):310-20. 